and was continuous with the pelvic fascia before and behind. It possessed, so far as I could see, no restige of proper muscular tissue; nor did the recto-vesical fold of the peritoneum appear. That membrane, on leaving the fundus of the bladder, was reflected over the enormous colon.

At the anal extremity, the appearances were natural. There was the retraction and puckering of the skin; and on dissecting deeper, the external sphincter was found perfect; but I cannot say that I discovered any circular band of muscle surrounding the pouch, which could be called the internal sphincter. The levatores ani were present and well developed, and together encircled the pouch just within the sphincter.

Milbrook, Southamptou, June $2 \%$ th, $185 \%$.

\section{HINTS ON THE CLIMATE OF AUSTRALIA.}

By w. J. STERLAND, Esq.

[This paper has been communicated to us hy Dr. Cowas, of Reading, who states that the author, though not a member of the medical profession, is entitled to spcak with authority on the climate of Australia. EDIтor.]

THE salubrity of the Australian climate has been so much raunted by almost every writer on the colonies of that vast continent, that it may appear an act of temerity in me to lift up my voice in opposition to the many who have lauded it as the healthiest climate in the world. Yet it is doubtful if these pages would have been written, had not an eminent physician suggested to me, that, having left England for Australia solely on the score of health, my experience of the climate might perhaps be useful to others; and it is on that account alone that I have ventured to pen the following remarks.

Before I set out for Australia, I had been suffering from ill health for some time; and, ere taking the important step of leaviner iny home for the antipodes, I very naturally consulted all the writers on the elimate on whose works I could lay my hands. All (with only one exception) agreed in their accounts of its advantages. The exception was a little work by Dr. Clutterbuck,* a nine years resident in the colony; his statement alone varied from the rest, and he alone painted the climate in the colours which my subsequent experience has found to be correct. I believe his little book met with a good deal of opposition from the advocates of the colony, the writer being described as a disappointed man, who was endeavouring to revenge himself by depreciating the colony on a point which had always been strenuously insisted on as one of its chief advantages. However that might be, I know not; but, so unfavourable was his statement as to the healthiness of the climate, that I studiously kept back this book from some of my friends on this account.

The principal part of Australia that is colonised lies between the 28th and 40th degrees of south latitude, the mean annual heat being about $65^{\circ}$ Fahr. In general, the atmosphere is a brilliant one; the extreme rarity and dryness of the air enabling one to see a far greater distance than is possible in England; indeed, the latter named quality, dryness, I believe to be its great characteristic. During the summer season, when there is a cool air stirring, there is a buoyancy in the atmosphere which I never felt elsewhere. Fren during the rainy winter season, the air possesses the same quality ; it may rain with almost tropical violence, but the air is free from dampness and clamminess; there are no walls streaming with condensed moisture, nor do the clothes steam on approaching the fire, as is so common in this country.

The season of spring commences in September, and is the most delightful part of the year; the ground is covered with an emerald verdure; and, though there are occasional showers, yet the sun shines brightly and cheerily, drying the ground which the heary winter rains have deeply softened; too

* Port Phillip in 1849. By J. B. Clutterbuck, M.D. Loudon: J. W. Parker. much 80, indeed, for the poor pedestrian, but not too much to fertilise the soil. In November, the summer heat commences, and then begins also that bane of the climate, the hot wind.

The interior of the vast continent of Australia, as far as it has been explored by Mitchell, Leichhandt, Sturt, and others, appears to be an interminable waste of sandy and rocky desert. Captain Sturt, who penetrated further to the northward than any other traveller, found himself in a desert of sandy hummocks alternating with bare rocks, and without a trace of vegetation or water. The heat was terrific; stones, that had lain on the ground in the sun, could with difficulty be held in the hand; the stirrups of the saddles became so hot, that the men could not always keep their feet in them; their nails became as brittle as glass; and all the horn handles of their combs and instruments split to pieces with the intense heat. A thermometer, hung in the shade at the back of a tree, rose to $132^{\circ} \mathrm{Fahr}$., and in the sun to $157^{\circ}$ ! Only one living creature was observed: the wonder is, that any should be found in such a glowing region; but, perched on the highest and most exposed points of the rucks, where it was too hot to bear the hand for long, sat a beautiful little pigeon, with a long crest, the geophays plumifera of Gould, seeming to find enjoyment in the heat which had driven all else living away.

The general opinion as to the cause of the hot wind is, that it becomes greatly heated in passing over the burning deserts just described; and I think the theory is so rational and sufficient to account for the effect:, that no other need be sought for. The great proof of its correctness is, that the hot winds invariably blow from the interior to the colonies affected by them. In Port Phillip (now Victoria) they always blow from the north, and indeed I do not remember a north wind that was not a hot one.

We could always tell en rising in a morning, and sometimes before we left our beds, if the wind was in the north, even if we could not feel the heut. The sky, though generally free from clouds, wears a hard leaden aspect; and though at first there may be only a rentle breeze, yet it soon increases in inteusity until it blows a perfect gale, driving the dust in clouds, while the sky has deepened into a lurid tint, and the sun has a coppery appearance. Every effort of course is made by those who have experienced the effects of these winds, to close all doors and windows, and every crevice that would admit a breath, in order to husband as lone as possible the cool air which the house contains. In small houses the temperature within and without doors soon assimilates, while in larger oncs the air can be maintained cool the whole day.

As the day advances, the heat of course increases, and the thermometer soon reaches $80^{\circ}$, but it still keeps rising until $82^{\circ}, 84^{\circ}, 86^{\circ}$, and sometimes $88^{\circ}$ and $90^{\circ}$ is attained; and this is within the house, and free from every breath of hot air. Out of doors in the shade the thermometer ranges from $90^{\circ}$ to $105^{\circ}$, and sometimes higher; and I have known one instance in which it rose on a south wall (the cool quarter) in the shade, and within three miles of the sea, to $110^{\circ} !$ !

During the summer senson, rarely a week passes without one or two days of hot wind. Sometimes it blows for two days together; and on one occasion I experienced it without the slightest intermission for five consecutive days. I was told by a medical man in Melbourne, that onc day more would have "laid half the people in Melbourne on their backs". The effects upon the human frame are, as may be imagined, extremely depressing; all energy is gone, onc feels utterly exhausted, and gasps for breath like a fish out of water; but it is in vain that one opens a window to admit a little air to keep off the feeling of suffocation; a blast rushes in as hot as if it had just traversed a furnace, and one is quickly glad to close the window. Night draws nigh, and the wind generally changes at night; yet still it rushes on in the same riolent monotonous manner. Suddenly there is a lull : one hastens to open the door. The hot wind has ceased; and in two minutes, sometimes less, 
sometimes, though rarely, more, roaring over the tree-tops comes a south breeze, charged with cold from the Arctic ocean, and for a few minutes driving back the dust which all day long had been blowing in the opposite direction. When this has subsided, doors and windows are thrown open with a glad welcome, and thicker clothing is put on.

But if the wind should not change in the evening, matters are still worse. In the daytime there is something to attract attention, if one is almost melted; but at night there is no such resource, and one fcels totally exhausted. Yet sleep is impossible; for the thermometer in the bedroom is never less than $84^{\circ}$ or $85^{\circ}$, and the heavy monotonous groaning of the wind, as it rushes past, sings anything but a lullaby. There is nothing left but to lie on the bed, waiting and hoping for a change with as much patience as can be mustered. Often have I risen in the night and opened the window, in the vain hope that perhaps the wind might have changed witliout our hearing it.

It is, I believe, the extreme vicissitudes of the Australian climate, the great and sudden changes of temperature, that are so injurious to the constitution and so productive of disare so the summer of 1851-2, on one occasion the ther mometer at the back of my house, in the shade and facing the cool quarter, stood at noon during the prevalence of a hot wind at $107^{\circ}$; the next day at the same time and place it stood at $52^{\circ}$ ! This, I grant, was an extreme case ; but I have frequently known a difference of from $10^{\circ}$ to $30^{\circ}$ in from two to five minutes, and indeed I never recollect an instance of $a$ hot wind occurring, when the change to a south wind did not take place in the sudden manner $I$ have described.

It must strike the most carcless observer that such vicissitudes cannot he beneficial to health, when one hour you are perspiring copiously under the thinnest possible clothing, and the next glad to get to the fire-side, or put on winter clothes.

Fever and dysentery (as might be expected) are very frequent; and rheumatism, notwithstanding the dryness of the air, is far more prevalent than in England, a fact clearly to be attributed to the sudden changes of temperature. Consumption, too, is frequent, and fearfully rapid in its course; but I helicve that, in its incipient stages, before any ulceration of the lungs has commenced, the Australian climate would prove remedial in its effects, if the extreme changes mentioned above were guarded against. Ophthalmia is very common, arising from the intense heat and glare of the sun, and the dust with which the air in summer is constantly loaded. During the summer of 1851-2, influenza made its appearance in the colony, and was very general in its ravares, few persons escaping a more or less severe attack.

I have found disease of every kind far more rapid in its course than in England; and generally speaking, it may be stated that the climate is fatal to the extremes of life, particularly to childhood, great numbers of children being annually carried off hy dysentery and inflammatory discases.

I have stated, at the commencement, that I visited Australia for the benefit of the climate, and the reader will be glad to learn with what success. The chicf disorders from which I suffered, were a delicacy of chest without the presence of actual disease, and an extreme susceptibility to take cold. On these two points I found the climate highly beneficial; I have nerer felt the least symptom of weakness of chest since I landed in Australia nor since my return, nor have 1 ever had but one cold or cough during the same period. But, on the other hand, I suffered much from the depressing influence of the hot winds, and twice I was laid up with low typhoid fever, and fully expecting that the last attack would prove fatal.

I do not pretend to account for the manner in which the diseases I have mentioned are produced; this I leave to the physician. I have merely chronicled the result of my own expcrience during a few years residence in the colony ; and the reader will be at no loss to gather that, on the whole, my opinion of the climate is unfavourable.

Great stress has been laid by writers on the Australian colonies on the fact, that persons, they say, may sleep out of doors without any danger. During the summer season, when little or scarcely any dew or rain falls, a man may easily do this without risk, wrapped in his blanket or opossum rug; but at other times of the year it is almost as impossible as in England, and it argues great ignorance, or perversion of the truth, to take a few isolated months and hold them forth as a specimen of the whole year.

I may, perhaps, usefully conclude these notes by a brief description of the seasons as they occur. Spring, as I have elsewhere said, commences in September; and during this and the following month the weather is particularly fine and exhilarating, with frequent genial showers.

Summer sets in with November, and continues until the end of February, the latter being the hottest munth of the year; the hot winds prevail during the whole of this season, and the dust during the same period is a constart plague. Within fifteen or twenty miles of the sea coast, the summer heat is tempcred by the sea brecze; but beyond that distance it is much more intense. In general, little rain falls during the summer; but destructive floods occasionally occur in Uecember, from heavy rains on the distant mountain ranges. March, April, and May, are the autumnal months, the last being frequently showery.

Vinter begins in June and continues through July and August. The rains during these months are heavy and fre quent, approaching the tropical in character. In the lowerlying country, the cold rarely produces more than occasional slight frosts, which are dissipated in an hour; on the high grounds and mountain ranges snow frequently falls to the depth of several inches, and ice is formed, of the thickness of a shilling, but neither last many days.

The mean annual depth of rain in Victoria is about fortyeight inches, the mean of London being only about twentytwo inches; a proof of the tropical nature of the winter rains, and of the rapid evaporation going on during the remainder of the year.

lieacius, July 1503 .

\section{MASTLRBATION IN A FEMALE APPARENTLY WITHOUT AN UTERLS; WITH REMARKS.}

\section{By FDWARD WADDINGTON, Esq.}

Tne following case came under my notice in the year 1848 , while in practice in the country. By a reference to my case book, I find ample details of the case; but, as it would take uj too much space to publish the whole, and as the case will lose nothing by being abridged, I shall adopt the latter plan.

Catherine Stevens, a finely formed, but sickly looking servant girl, aged 22, applied to me on account of frequent pains in the back, passing round to the loins. Upon inquiry, I found that these pains were first noticed about the age of sixteen, but were of so slight a nature, and so short in duration, as to attract but little notice. For the last few years, however, she had suffered more and more; the pains in her back appearing gradually to increase in strength and duration, recurring as nearly as possible every two or three weeks, seldom leaving so long an interval as a month, and lasting about three days. When first noticed, some years since, they did not continue more than half a day, or a right. She had necer menstruated. From the peculiar pasty yellow appearance of the features, the tumid, discoloured semicircle beneath the cyes, the pearly conjunctiva, the tremulous white tongue, and feeble pulse, I came to the conclusion that this was simply a case of amenorrhoa. For months I continued to treat this person for delayed menstruation. She took at various times, one after the other, almost all the emmenagogues in repute; but all were of no avail. She was cupped on the loins; had leeches applied to the vulva, and insides of the thighs; used hip-baths, etc. with no apparent benefit. I therefore insisted upon a personal with no apparent bencft. I therefore nnatural impediment existed to render the further perseverance in medical treat- 